\title{
Determinants of Disability in Patients with Leprosy at Kelet Hospital, Central Java
}

\author{
Umi Nadhiroh"), Ruben Dharmawan²), Bhisma Murti1) \\ 1)Masters Program in Public Health, Universitas Sebelas Maret \\ 2)Faculty of Medicine, Universitas Sebelas Maret
}

\begin{abstract}
Background: Leprosy is a chronic disease caused by Mycobacterium leprae. World Health Organization (WHO) reported that the number of leprosy cases in 2015 was 211,973 in 108 countries in the world. The number of leprosy cases in Indonesia ranks third after India and Brazil. There are 14,000 (8\%) leprosy cases with disability. This study aimed to determine factors affecting disability and Years of Life with Disability (YLD) attributable to leprosy in patients with leprosy at Kelet Hospital, Central Java.

Subjects and Method: This was an analytic observational study with case control design. The study was conducted at Kelet Hospital, Central Java, from December 2017 to January 2018. A total sample of 140 leprosy patients was selected for this study using fixed disease sampling, consisting of 70 patients with disability and 70 patients without disability. The dependent variables were disability and YLD. The independent variables were age, education level, and self care. The data were collected by questionnaire and analyzed by path analysis.

Results: Disability increases YLD ( $b=0.37 ; 95 \% \mathrm{CI}=0.31$ to $0.43 ; \mathrm{p}<0.001)$. Disability increased with older age $(b=1.41 ; 95 \% \mathrm{CI}=0.38$ to $2.43 ; \mathrm{p}=0.007)$ and decreased with better self care $(\mathrm{b}=-$ 3.80 ; $95 \% \mathrm{CI}=-4.90$ to $-2.71 ; \mathrm{p}<0.001)$. Better self care increased with high education level $(\mathrm{b}=$ $1.96 ; 95 \% \mathrm{CI}=1.03$ to $2.89 ; \mathrm{p}<0.001)$.

Conclusion: Older age increases the risk of disability, whereas self care decreases the risk of disability. Disability itself increases YLD. Higher education improves self care.
\end{abstract}

Keywords: leprosy, disability, years of life with disability, determinant

\section{Correspondence:}

Umi Nadhiroh. Masters Program in Public Health, Universitas Sebelas Maret, Jl. Ir. Sutami 36 A, Surakarta, 57126, Central Java. Email: umi.nadhiroh2@gmail.com.

Mobile: 085727056553 .

\footnotetext{
BACKGROUND

Leprosy is a chronic infection caused by Mycobacterium Leprae. The World Health Organization (WHO) reported the number of new global leprosy cases by 2015 of 211,973 cases from 108 countries worldwide. Leprosy patients in Indonesia ranked third after India and Brazil. There were more than 14,000 (8\%) new cases of leprosy with disabilities (World Health Organization, 2016).

In Indonesia, new leprosy patients recorded as many as 17,202 cases in 2015 with $84.5 \%$ of cases were Multi Bacillary
}

(MB) type leprosy. By gender, new male leprosy patients were as many as $62.7 \%$. Leprosy patients with level 2 disabilities were 6.60 per 1 million population (Ministry of Health RI, 2016). Central Java provincial health profile data in 2015 showed that the number of new cases of both Paucy Bacillary (PB) and Multi Bacillary (MB) type leprosy patients amounted to 1,801 cases. The number of PB type leprosy patients who finished treatment was 90\%. The number of MB type leprosy patients was 85\% (Central Java Provincial Health Office, 2015). 
Journal of Epidemiology and Public Health (2018), 3(2): 143-252

https://doi.org/10.26911/jepublichealth.2018.03.02.04

Disability due to leprosy increases after treatment completion. Disabilities include limb dysfunction, activity limitations, discrimination, stigma, and social limitations (Brakel et al., 2012). Disability occurs due to progressively impaired nerve function in the eyes, hands, or feet. This acute destruction of nerve function is caused by leprosy reaction (Ministry of Health, 2012).

Leprosy reaction is a period of inflation experienced by leprosy patients who may occur before, during, or after treatment. There are 2 types of leprosy reactions, type 1 and type 2 reactions. A study by Ranque et al. (2007) concluded that MB type leprosy was 4 times more likely to experience leprosy reactions than PB type leprosy. Leprosy patients with more than 5 lesions had a 3 times greater risk, positive index bacteria at risk 3 times greater, and age at leprosy diagnosis over 15 years were twice as likely to have leprosy reactions. The study by Hungria et al. (2016) showed that $55.5 \%$ of study subjects experienced leprosy reactions in the first year after leprosy diagnosis and leprosy reactions were more common in MB type leprosy patients.

Leprosy reactions that were not diagnosed and treated quickly and appropriately would cause impaired neurological function and disability (Ministry of Health, 2012). Impairment occurs in people suffering from leprosy for $0-5$ years. Leprosy reactions will increase in patients with long-term leprosy or old leprosy.

The data from a preliminary study at Kelet Hospital, Jepara, Central Java, the number of inpatient visits from January to August 2017 were 361 patients, including 280 old leprosy patients and 81 new leprosy patients. The number of outpatient visits from January to August 2017 was 1,520 people, including 1,392 old leprosy patients and 128 new leprosy patients. New leprosy patients tended to increase every month. The leprosy patients did not know that they had leprosy. Most of the visiting patients were already in the inflammatory stage or had leprosy reactions, so they were at greater risk of disability.

Based on the background, the author was interested to examine the determinants of disability in leprosy patients at Kelet Hospital, Jepara, Central Java.

\section{SUBJECTS AND METHOD}

\section{Study Design}

This was an analytic observational study with a case control design.

\section{Population and Sampel}

Target population was all leprosy patients. Source population was leprosy patients at Kelet Hospital, Central Java.

The selection of leprosy inpatients (from the hospital) because the study subjects tended to prefer hospitalization rather than being treated at home. The selection of leprosy outpatient because the number of outpatients had met the minimum required sample size for the study. The limited study time was another recent for consideration.

A sample of 140 leprosy patients was selected for this study by fixed disease sampling with case: control ratio $=1: 1$.

The inclusion criteria included the study subjects who were or had completed treatment of Multi-Drug Therapy (MDT), were able to communicate well, and willing to sign informed consent. The exclusion criteria included undiagnosed leprosy, had never received leprosy treatment, and had other disease complications.

\section{Study variables}

The dependent variable was years lived with disability (YLD). The independent variables included disability, sex, age, duration of illness, and self-care. 


\section{Operational definition of variables}

Age was defined as length of life of the individual calculated from the year of birth to the time of study. The measurement scale was continuous, but for the purpose of analysis was transformed into dichotomous coded o for $<38$ years old and 1 for $\geq 38$ years old.

Sex was defined as the biological identity of the study subject. The measurement scale was categorical coded o for male and 1 for female.

Education was defined as the highest attained level of formal education by the study subject. The measurement scale was categorical coded o for $<$ Senior high school and $1 \geq$ Senior high school.

Type of leprosy was defined as the type of leprosy suffered by the study subject using the WHO classification. The measurement scale was categorical coded o for wet leprosy (Multi Bacillary / MB) and 1 for dry leprosy (Paucy Bacillary/PB).

Duration of illness was defined as the length of the study subjects suffered from leprosy which was calculated from starting to receive Multi-Drug Therapy. The measurement scale was continuous, but for the purpose of analysis, was transformed into dichotomous, coded o for $<60$ months and 1 for $\geq 60$ months.

Duration of treatment was defined as the length of the study subjects was undergoing regular treatment, provided that it did not exceed 6 months for PB type leprosy and 12 months for MB type leprosy. The measurement scale was continuous (month).

Self-care was defined as an act of maintaining cleanliness and personal hygiene performed by a person. The measurement scale was continuous, but for the purpose of analysis, was transformed into dichotomous, coded o for poor self-care and 1 for good self-care.
Disability was defined as state of skin or nerve disorders of the eyes, feet, and hands suffered by leprosy patients. The disability level was determined according to WHO standard used by Indonesia Ministry of Health. The measurement scale was categorical coded o for no and 1 for yes.

Years lived with disability (YLDs) was defined as a measurement of the burden of leprosy disease. YLDs were calculated by multiplying the prevalence of a disorder by the short- or long-term loss of health associated with that disability (the disability weight). The measurement scale was continuous.

\section{Study instrument}

The instrument of this study was a questionnaire to measure the variables age, sex, duration of illness, duration of treatment, and regularity of treatment. The observational checklist was used to measure the level of disability of leprosy patients in accordance with the WHO provisions. The self-care questionnaire referred to the care guidelines of leprosy patients used by the Ministry of Health (2012).

\section{Data analysis}

Sample characteristics were described by univariate analysis. Bivariate analysis used Chi square. Multivariate analysis used path analysis to determine the direct and indirect effects of the relationships between study variables. Path analysis steps includeed model specification, model identification, model fit, parameter estimate, and model re-specification.

\section{Research ethics}

The research ethical clearance was obtained from the Research Ethics Committee at Dr. Moewardi Hospital, Surakarta, Central Java, Indonesia. Research ethics included issues such as informed consent, anonymity, confidentiality, and ethical clearance. 
Journal of Epidemiology and Public Health (2018), 3(2): 143-252

https://doi.org/10.26911/jepublichealth.2018.03.02.04

\begin{tabular}{l}
\hline RESULTS \\
\hline 1. Sample characteristics \\
Characteristics of study subjects are \\
displayed in Table 1 . Table 1 shows that the \\
mean age of the case group was 38 years. As \\
many as 45 people $(63.4 \%)$ and control \\
group 44 people (63.8\%) aged $\geq 38$ years. \\
As many as 45 people (51.1\%) in the case \\
group were male and 43 people $(48.9 \%)$ in \\
the control group were female.
\end{tabular}

As many as $43(39.1 \%)$ study subjects in the case group and $65(50.2 \%)$ in the control group had education $\geq$ Senior high school. As many as 69 (49.6\%) study subjects in the case group and 70 (50.4\%) in the control group suffered from MB type leprosy.

As many as 36 (48.0\%) of the study subjects in the case group and 39 (52.0\%) in the control group suffered leprosy less than 60 months. As many as 65 (49.2\%) study subjects in the case group and 67 (50.8) in the control group were treated regularly. As many as 65 (49.2\%) of the study subjects in the case group and 67 (50.8\%) in the control group had good selfcare.

Table 1. Sample characteristics

\begin{tabular}{|c|c|c|c|c|}
\hline \multirow{2}{*}{ Characteristics } & \multicolumn{2}{|c|}{ Case } & \multicolumn{2}{|c|}{ Control } \\
\hline & $\mathbf{n}$ & $\%$ & $\mathbf{n}$ & $\%$ \\
\hline \multicolumn{5}{|l|}{ Age } \\
\hline$<38$ years & 25 & 36.2 & 44 & 63.8 \\
\hline$\geq 38$ years & 45 & 63.4 & 26 & 36.6 \\
\hline \multicolumn{5}{|l|}{ Sex } \\
\hline Male & 45 & 51.1 & 43 & 48.9 \\
\hline Female & 25 & 48.1 & 27 & 51.9 \\
\hline \multicolumn{5}{|l|}{ Education } \\
\hline$<$ Senior high school & 27 & 84.4 & 5 & 15.6 \\
\hline$\geq$ Senior high school & 43 & 39.8 & 65 & 50.2 \\
\hline \multicolumn{5}{|l|}{ Type of leprosy } \\
\hline MB type & 69 & 49.6 & 70 & 50.4 \\
\hline PB type & 1 & 100.0 & 0 & $\mathrm{O}$ \\
\hline \multicolumn{5}{|l|}{ Duration of illness } \\
\hline$<60$ months & 36 & 48.0 & 39 & 52.0 \\
\hline$\geq 60$ months & 34 & 52.3 & 31 & $47 \cdot 7$ \\
\hline \multicolumn{5}{|l|}{ Regularity of treatment } \\
\hline Irregular & 5 & 62.5 & 3 & 37.5 \\
\hline Regular & 65 & 49.2 & 67 & 50.8 \\
\hline \multicolumn{5}{|l|}{ Self-care } \\
\hline Poor & 5 & 62.5 & 3 & $37 \cdot 5$ \\
\hline Good & 65 & 49.2 & 67 & 50.8 \\
\hline
\end{tabular}

Table 2 shows the results of bivariate analysis between disability and age, sex, education, leprosy type, duration of illness, duration of treatment, and self-care. Some of these crude analyses tentatively support the relevant hypotheses. For example, leprosy patients with good self-care were less likely to have disability than patients with poor self-care $(\mathrm{OR}=0.02 ; \mathrm{p}<0.001)$. Likewise, older leprosy patients were more likely to have disability than the younger patients $(\mathrm{OR}=3.04 ; \mathrm{p}<0.001)$. 
Table 2. Bivariate analysis

\begin{tabular}{|c|c|c|c|c|c|c|c|c|c|}
\hline \multirow{3}{*}{ Variable } & \multicolumn{4}{|c|}{ Disability } & \multirow{2}{*}{\multicolumn{2}{|c|}{ Total }} & \multirow{3}{*}{$\mathbf{O R}$} & \multirow{3}{*}{$95 \% \mathrm{CI}$} & \multirow{3}{*}{ p } \\
\hline & \multicolumn{2}{|c|}{ No } & \multicolumn{2}{|c|}{ Yes } & & & & & \\
\hline & $\mathbf{n}$ & $\%$ & $\mathbf{n}$ & $\%$ & $\mathbf{n}$ & $\%$ & & & \\
\hline Age & & & & & & & \multirow{3}{*}{3.04} & \multirow{4}{*}{$\begin{array}{l}1.53 \text { to } \\
6.06\end{array}$} & \multirow{4}{*}{$<0.001$} \\
\hline$<38$ years & 44 & 63.8 & 25 & 36.2 & 69 & 100.0 & & & \\
\hline$\geq 38$ years & 26 & 36.6 & 45 & 63.4 & 71 & 100.0 & & & \\
\hline Sex & & & & & & & \multirow{3}{*}{0.88} & & \\
\hline Male & 43 & 48.9 & 45 & 51.1 & 88 & 100.0 & & \multirow{3}{*}{$\begin{array}{c}0.44 \text { to } \\
1.75\end{array}$} & \multirow[t]{2}{*}{0.726} \\
\hline Female & 27 & 51.9 & 25 & 48.1 & 52 & 100.0 & & & \\
\hline Education & & & & & & & & & \multirow{3}{*}{$<0.001$} \\
\hline$<$ Junior high school & 5 & 15.6 & 27 & 84.4 & 32 & 100.0 & \multirow[t]{2}{*}{0.12} & \multirow{2}{*}{$\begin{array}{c}0.04 \text { to } \\
0.34\end{array}$} & \\
\hline$\geq$ Junior high school & 65 & 60.2 & 43 & 39.8 & 140 & 100.0 & & & \\
\hline Type of leprosy & & & & & & & \multirow{3}{*}{0.49} & \multirow{3}{*}{$\begin{array}{c}0.42 \text { to } \\
0.58\end{array}$} & \multirow{3}{*}{0.316} \\
\hline PB type & 0 & 0.0 & 1 & 100.0 & 1 & 100.0 & & & \\
\hline MB type & 70 & 50.4 & 69 & 49.6 & 139 & 100.0 & & & \\
\hline Duration of & & & & & & & \multirow{3}{*}{1.18} & \multirow{3}{*}{$\begin{array}{c}0.61 \text { to } \\
2.31\end{array}$} & \multirow{3}{*}{0.611} \\
\hline $\begin{array}{l}\text { illness } \\
<60 \text { months }\end{array}$ & 39 & 52.0 & 36 & 48.0 & 75 & 100.0 & & & \\
\hline$\geq 60$ months & 31 & 47.7 & 34 & 52.3 & 65 & 100.0 & & & \\
\hline $\begin{array}{l}\text { Duration of } \\
\text { treatment }\end{array}$ & & & & & & & & & \\
\hline Irregular & 3 & 37.5 & 5 & 62.5 & 8 & 100.0 & \multirow[t]{2}{*}{0.58} & $\begin{array}{c}0.13 \text { to } \\
2.53\end{array}$ & \multirow[t]{2}{*}{0.466} \\
\hline Regular & 67 & 50.8 & 65 & 49.2 & 132 & 100.0 & & & \\
\hline Self-car & & & & & & & \multirow{3}{*}{0.02} & \multirow{3}{*}{$\begin{array}{c}0.01 \text { to } \\
0.07\end{array}$} & \multirow{3}{*}{$<0.001$} \\
\hline Poor & 6 & 9.8 & 55 & 90.2 & 61 & 100.0 & & & \\
\hline Good & 64 & 81.0 & 15 & 19.0 & 79 & 100.0 & & & \\
\hline
\end{tabular}

\section{Path analysis}

Path analysis used Stata 12 program. Path analysis steps including:

a. Model specification

b. Model identification

c. Model fit

d. Parameter estimation

e. Model re-specification

The number of observed variables was 7 , endogenous variables were 3 , exogenous variables were 4 , and the number of parameter was 6. Degree of freedom value was 15 , indicating that sample size was sufficient for running path analysis. Figure 1 shows the path analysis structural model including the parameter estimates. Table 2 shows the results of path analysis, including direct and indirect effect estimates.

Table 2 shows that years lived with disability increased with disability $(b=0.37$;
$95 \% \mathrm{CI}=0.31$ to $0.43 ; \mathrm{p}<0.001$ ), indicating that the more years living with disability, the more burden of illness the leprosy patients had.

Age $\geq 38$ years old $(b=1.41 ; 95 \% \mathrm{CI}=$ 0.38 to $2.43 ; \mathrm{p}=0.007)$, female $(\mathrm{b}=0.10$; 95\% $\mathrm{CI}=-0.92$ to $1.14 ; \mathrm{p}=0.839)$, and duration of illness $(b=0.37 ; 95 \% \mathrm{CI}=-0.60$ to $1.35 ; \mathrm{p}=0.454$ ) increased the likelihood of disability in leprosy patients.

Good self-care $(b=-3.80 ; 95 \% \mathrm{CI}=-$ 4.90 to $-2.71 ; \mathrm{p}<0.001)$ decreased the likelihood of disability in leprosy patients.

Education has indirect effect on disability in leprosy patients through selfcare. Leprosy patients with higher education level have better self-care and therefore are less likely to have disability. Conversely, leprosy patients with lower 
Journal of Epidemiology and Public Health (2018), 3(2): 143-252

https://doi.org/10.26911/jepublichealth.2018.03.02.04

education level have worse self-care and therefore are more likely to have disability.

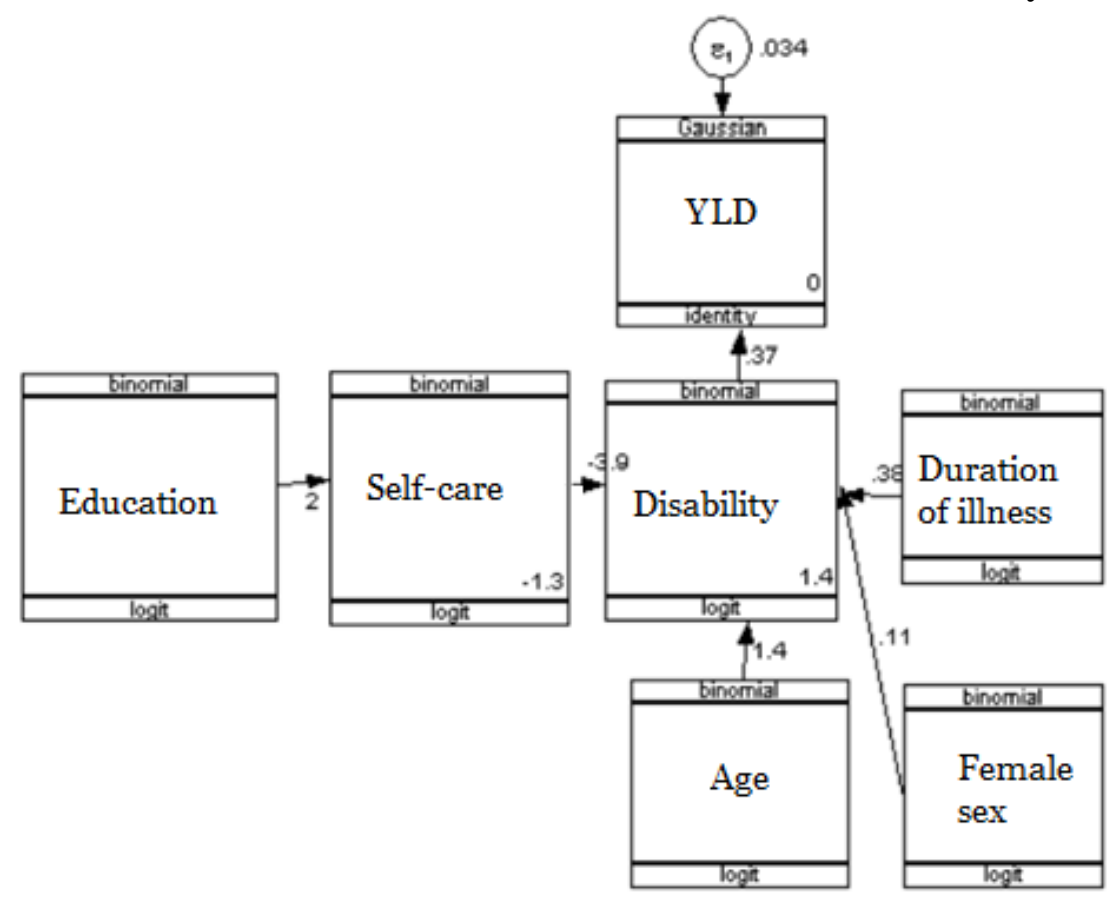

Figure 1. Structural model with estimation

Table 2. The results of path analysis on the determinants of the disability in leprosy patients

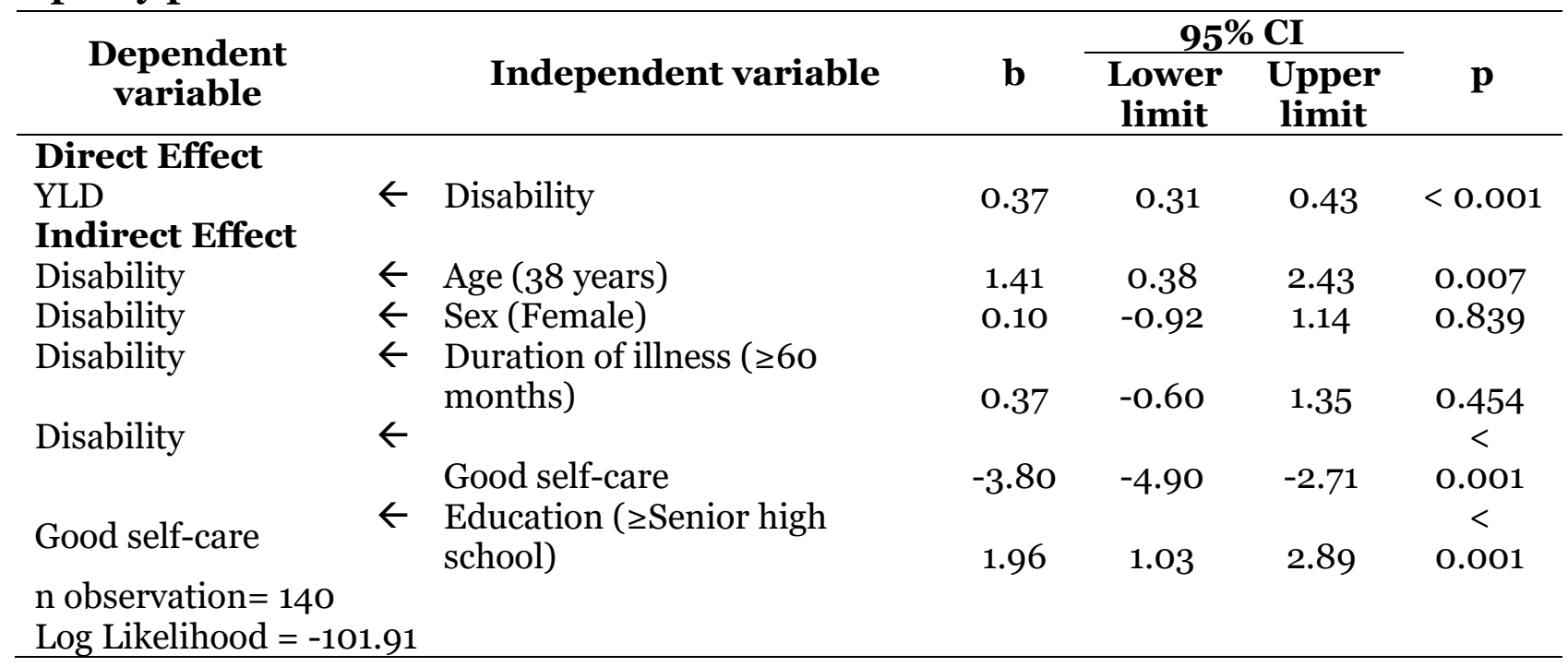

\section{DISCUSSION}

\section{The association between age and} disability in leprosy patients

The result of this study showed that age had a direct effect on leprosy disability and it was statistically significant. Age is an important factor of functional disability and self-care. The result of this study is consistent with De Araujo et al. (2014) and De Oliveira and Diniz (2016) which stated that age 31-45 years and over 60 years were at risk for physical disability. Children between 10 to 14 years old are the most vulnerable to leprosy. Adolescents with leprosy can be depressed and lose self- 
esteem. Health support for adolescents and families is needed for adolescents with leprosy (Yamaguchi et al, 2013).

In addition, women have been reported to be at higher risk of having a functional disability and poor self-care than men (Tareque et al., 2017). Mowla et al. (2017) reported that $70 \%$ of leprosy occurred in male and age group $\geq 40$ years.

\section{The association between education} and disability in leprosy patients

The results of this study showed that education had an indirect effect on disability of leprosy. Education level affects treatment adherence in leprosy patients. Low level of education causes leprosy patients to take medicine irregularly, so disability gets worse (Peters and Eshiet, 2002). The result of this study is consistent with Porto et al. (2015) which stated that $70 \%$ of study subjects affected by leprosy disability had an incomplete primary education. Low education affects leprosy patients to not care for wound conditions due to leprosy disease so that the defect worsens (Iyor, 2005).

\section{The association between self-care and disability in leprosy patients}

Hasil The result of this study showed that self-care had a direct effect on leprosy disability. According to Ridley (1985), good self-care reduces the incidence of leprosy reactions (Brehmer-andersson, 2006).

Navidian et al. (2015) who evaluated the effect of self-care education on self-care behavior showed that patients with selfcare education had a lower risk of depression.

Leprosy patients who obtained leprosy-specific health services were more likely to start treatment appropriately. Treatment delays are influenced by a lack of leprosy knowledge and low patient health priorities. Specialized health services for leprosy are needed to provide support and integrated health of leprosy diagnosis and management (Raffe et al., 2013).

Health personnel support is needed for leprosy patients to routinely care for wound injuries (Guimarães et al., 2009). Utilization of technology can be used to empower leprosy patients in self-care (Maia et al., 2016).

Muthuvel et al. (2017) reported that delayed treatment of leprosy patients was influenced by a lack of awareness of leprosy symptoms and lack of involvement of health workers when making an initial diagnosis of leprosy. Integrated leprosy monitoring activities for health services, knowledge, and skills of leprosy diagnosis, treatment, and management by health personnel should be given attention. Training can increase leprosy knowledge and promote better leprosy management at community health facilities (Abeje et al., 2016).

People affected by leprosy have a low quality of life in terms of physical and psychological health (Savassi et al., 2014). Social participation restriction was experienced by about 70\% of leprosy patients. Activation of leprosy groups can strengthen the leprosy patients' pride and prevent further disability. Self-care groups will be more effective when combined with other diseases such as diabetes because social constraints will be addressed between the diseases (de Vries, de Groot and van Brakel, 2014).

\section{The association between disability and years of lived with disability}

The results of this study showed that leprosy disability had contributed to the burden of leprosy disease in Years Lived with Disability (YLD). The burden of leprosy disease calculated on the basis of the YLD value contributes $37 \%$ to DALY.

Years Lived with Disability is the measurement of the number of years 
passed in a defective or nonproductive state due to a disease either temporary or permanent (Donev et al., 2013). The concept of global burden disease or the Global Burden Disease (GBD) began to be published in 1996 by WHO. This concept is the most comprehensive and consistent concept in estimating disease mortality and morbidity. The GBD concept uses a simple measure of population health, which is Disability Adjusted Life Years (DALYs) that combine Years Life Lost (YLL) and Years Live with Disability (YLD) (Pruss-Ustun et al., 2003).

This study concludes that leprosy disability has a contribution to leprosy disease burden in YLD. Leprosy disability is affected by age, education, and self-care.

\section{REFERENCE}

Abeje T, Negera E, Kebede E, Hailu T, Hassen I, Lema T, Yamuah L, et al (2016). Performance of general health workers in leprosy control activities at public health facilities in Amhara and Oromia States, Ethiopia, BMC Health Services Research. BMC Health-Services Research, 16(1): 1-8. doi:10.1186/s12913-016-1329-2.

Brakel WH, Benyamin S, Hernani D, Kerstin S, Laksmi K, Rita Y, Indra, K, et al. (2012). Disability in people affected by leprosy: the role of impairment, activity, social participation, stigma and discrimination. Global health action, 5,1-11. doi: 10.3402/gha.v5io.18394.

Brehmer-andersson E (2006). Dermatopathology, in Gabriele-Schroder, H. (ed). Sweden, 110-3.

De Araujo E Araujo AER, Dorlene MCD, Isabel Maria BG, Silma Regina FP, Ivan Abreu F, Humberto Oliveira S, Poliana Cristina DF, et al. (2014) Factors associated with neural altera- tions and physical disabilities in patients with leprosy in São Luis, State of maranhão, Brazil, Revista da Sociedade Brasileira de Medicina Tropical, 47(4): 490-497. doi:- 10.1590/00378682-0119-2014.

De Oliveira MB and Lucia Martins D (2016). Leprosy among children under 15 years of age: Literature review, Anais Brasileiros de Dermatologia,-91(2): 196-203. Doi: 10.1590/abd1806-4841.20163661.

De Vries Henry JC, de Groot R, Wim H van Brakel (2014). Social Participation of Diabetes and Ex-Leprosy Patients in the Netherlands and Patient Preference for Combined Self-Care Groups, Frontiers in Medicine, 1-August,1-6. doi: 10.3389.

Dinas Kesehatan Provinsi Jawa Tengah (2015). Profil Kesehatan Provinsi Jawa Tengah. 48-49.

Donev D, Lijana ZK, Vesna B, Genc B, et al. (2013). Measuring the Burden of Disease: Disability Adjusted Life Year (DALY). Health Investigation: Analysis-Planning-Evaluation, 393-416.

Guimarães Heloisa CQCP, Alba LBL Barros, Sidineia RB Bassoli, Selma RA Salotti, Roseli M Oda, Margaret Lunney, et al (2009). Helping a man with leprosy: a case study. International journal of nursing terminologies and classi-fications: the official journal of NANDA International, 20(3), 141-144. doi: 10.1111/j.1744-618X.2009.01126.x.

Hungria EM, Regianne MO, Gerson OP, Lucio CA, Maria AAP, Rossilene C, Heitor de Sa G, et al (2016). Can baseline ML Flow test results predict leprosy reactions? An investigation in a cohort of patients enrolled in the uniform multidrug therapy clinical trial for leprosy patients in Brazil. Infectious Diseases of Poverty, 5, 110. 
https://doi.org/10.1186/s40249-0160203-0.

Iyor FT (2005). Knowledge and attitude of Nigerian physiotherapy students about leprosy, Asia Pacific Disability Rehabilitation Journal, 16(1): 85-92. http://english.aifo.it/disability/apdrj/ apdrj105/nigerian.pdf.

Kementerian Kesehatan RI (2012). Pedoman Nasional Program Pengendalian Penyakit Kusta. Jakarta.

(2016). Profil-Kesehatan Indonesia 2015. Jakarta.

Maia FB, Eneas Rangel T, Gislaine Valerie S, Maria Katia G, et al (2016). The Use of Assistive Technology to Promote Care of the Self and Social Inclusion in Patients with Sequels of Leprosy. PLoS Neglected Tropical Diseases, 10(4): 1-12. doi: 10.1371/journal.pntd.0004644.

Mowla MR, Ara S, Rahman AFM, Tripura SP, Paul S, et al (2017). Leprosy reactions in postelimination stage: the Bangladesh experience, Journal of the European Academy of Dermatology and Venereology. Wiley Online Library, 31(4): 705-711. doi: 10.1111/jdv.14049.

Muthuvel T, Srinivas G, Petros I, Hemant Deepak S, Vasudev R, Rajbir S, Sanjeev K, et al (2017). I Wasted 3 Years, Thinking It's Not a Problem": Patient and Health System Delays in Diagnosisof Leprosy in India: A Mixed-Methods Study. PLoS Neglected Tropical Diseases, 11(1), 1-15. doi: 10.1371/journal.pntd.ooo5192.

Navidian A, Fariba Y, Alireza G, Sadegh K, et al (2015). The effect of self-care education on the awareness, attitude, and adherence to self-care behaviors in hospitalized patients due to heart failure with and without depression, PLoS ONE, 10(6), 1-14. doi:-10.-- 1371/journal.pone.0130973.

Peters ES and Eshiet AL (2002). Malefemale (sex) differences in leprosy patients in south eastern Nigeria: females present late for diagnosis and treatment and have higher rates of deformity. Lepr Rev, 73(3), 262-7. http://www.ncbi.nlm.nih.gov/pubmed/12449892.

Porto ACS, Renata Borges FCF, Jason Antonio B, Jose Roberto PL, et al (2015). Evaluation of the social, clinical and laboratorial profile of patients diagnosed with leprosy in a reference center in S??o Paulo. Anais Brasileiros de Dermatologia, 90(2),-169-177. doi: 10.1590/abd1806-4841.20153385.

Prüss-Üstün A, Mathers C, Corvalan C, Wooward A, et al (2003). The GlobalBurden of Disease concept. Introduction and methods: Assessing theenvironmental burden of disease atnational and local levels., 27-40.

Raffe SF, Min T, Saraswoti K, Krishna T, Deanna H, Diana NJL, et al (2013). Diagnosis and Treatment of Leprosy Reactions in Integrated Services - The Patients' Perspective in Nepal. PLoS Neglected Tropical Diseases, 7(3). doi: 10.1371/journal.pntd.ooo2089.

Ranque B, Van Thuc N, Hong Thai V, Thu Huong N, Ngoc Ba N, Xuan Khoa P, Erwin S, et al (2007). Age Is an Important Risk Factor for Onset and Sequelae of Reversal Reactions in Vietnamese Patients with Leprosy. Clinical Infectious Diseases, 44(1), 33-40. https://doi.org/10.1086/509923.

Savassi LCM, Tatiana Roberta SB, Anna Carolina LL, Celina MM, et al. (2014). Quality of life of leprosy sequelae patients living in a former leprosarium under home care: univariate analysis. Quality of life research: an 
Journal of Epidemiology and Public Health (2018), 3(2): 143-252

https://doi.org/10.26911/jepublichealth.2018.03.02.04

international journal of quality of life aspects of treatment, care and rehabilitation, 23(4): 1345-1351. doi: 10.1007/s11136-013-0590-7.

Tareque MI, Andrew DT, Towfiqua MI, Sharifa B, Yasuhiko S, et al (2017). Gender differences in functional disability and self-care among seniors in Bangladesh, BMC Geriatrics. BMC Geriatrics, 17(1), 1-13. doi:-10.1186/- s12877-017-0577-2.

Yamaguchi N, Poudel KC, Jimba M (2013). Health-related quality of life, depression, and self-esteem in adolescents with leprosy affected parents: results of a cross-sectional study in Nepal.

World Health Organization (2016). Leprosy: lessons to be learnt in overcoming discrimination and stigmatization. Geneva. 